GAP GYAN - An International Peer-Reviewed

Open Access Journal of Social Sciences

\title{
A Study on Legal Aspects of Marine Environmental Protection in India
}

\author{
Foram Amrishbhai Pandya \\ Research Scholar, \\ University School of Law, Gujarat University, Ahmedabad \\ foram1593@yahoo.com \\ Dr. Bhavesh H. Bharad \\ Assistant Professor, \\ University School of Law, Gujarat University, Ahmedabad \\ dr.bharad@gmail.com
}

\begin{abstract}
Around the world more than 3 billion people are directly or indirectly dependent on our oceans for food, medicines, shelter, and livelihood. Industries like sea food, tourism and transportation provides livelihood to millions of people around the globe. Due to climate change and various human activities like oil spills, dumping of waste and extensive sea bed mining, the quality of the oceans as well as the quality and health of various flora and fauna inhabiting the oceans have been adversely affected. This in turn causes harm to the human beings and their health thus violating their basic human right to a healthy life. A clean, safe and healthy environment is a precondition for overall wellbeing of every human being. The Indian Judiciary has encouraged an innovative approach to environmental rights in the country. Judicial activism has provided impetus to campaign against various environmental pollution issues arising in the country in recent times. The Indian Judiciary has interpreted Art. 21 to give it an expanded meaning to bring within its ambit the right of every citizen to a clean, safe and healthy environment. The Judiciary while showing keen interest in the environmental issues affecting various aspects of the life of human beings passed appropriate orders, directions and writs against persons adversely affecting the environment. The Parliament of India has also made efforts to protect and preserve the marine environment by ratifying various international agreements, treaties and conventions. Currently efforts are being made at local, national and international level to build Marine Protected Areas (MPAs); local communities are also standing up for their right to healthy environment and to address the issue of accumulation of plastic and such other toxic substances in the oceans. But still a lot of ocean conservation efforts, through laws designed to manage fisheries, land based pollution, formation of Marine Protected Areas (MPAs), strict regulation of various hazardous industrial activities and processes, anti-dumping laws and coastal waste management laws are required to address the issue of marine environment pollution. Moreover lack of awareness among citizens is also a major impediment in the field of marine environment conservation which also needs to be addressed adequately.
\end{abstract}

\section{INTRODUCTION}

The term environment has a very broad meaning, but basically it includes air, water, and land and signifies the interaction between various human activities, processes and the natural world. In India since the ancient times i.e. the Vedic period it has been the motive of human kind to protect the environment and to live in harmony with the surrounding environment and various creatures inhabiting the earth. But in modern times the concept of environment has changed and has been greatly analyzed and interpreted by various scientists, environmentalists and researchers.

Biodiversity or Biological diversity means the variability among all living organisms from all sources including, terrestrial, marine and other aquatic ecosystems. It is the variety of life forms within a particular area. It is the 


\section{GAP GYAN - $\begin{aligned} & \text { An International Peer-Reviewed } \\ & \text { Open Access Journal of Social Sciences }\end{aligned}$}

variation within various species of plants, animals and micro-organisms and the ecosystems within which they inhabit and interact. ${ }^{1}$

Marine biodiversity includes coastal and marine plant and animal species, their genetic variety, the habitats and ecosystems of which they form a part. The marine pollution has a direct and a major impact on both marine as well as terrestrial environments. So there is a need to analyze relationship between marine life, human beings and the environment.

The innumerable negative impacts of various human activities on the environment must be measured and assessed and various relevant policies must be formulated to conserve our environment. Moreover the said policies, rules and regulations also need to be adequately implemented and executed not just at international level but also at local and national level.

Also various international agreements and conventions need to be ratified by the individual countries of the world and make them a part of their country's legal system. Such active participation of all the countries of the world is important because harmful effects on the environment do not only affect one nation or person in isolation, instead they have profound impact on the entire planet and each human and life form inhabiting the earth in various complex manner.

Clean and healthy environment is basic to the survival of human society but ironically it is the various human activities that are responsible for causing large scale pollution on the land as well as the seas and in the air. The abuse and excessive exploitation of natural resources have led to depletion of resources which are vital to human survival.

\section{ENVIRONMENT AND HUMAN RIGHTS}

Human rights are rights which are inherent to all human beings right from his birth without any discrimination as to sex, race, nationality, ethnicity, language, religion, or any other criteria. Right to live in a safe, clean and healthy environment is a basic right of every human born on this planet.

In recent years the relationship between human rights and environmental issues has become a subject of lot of controversies and debate. A decent environment is a precondition for living a life of dignity and worth. International community has taken many measures to protect and preserve the environment for the present as well as the future generation by arranging many international conferences, conventions and treaties.

Millions of annual deaths and billions of cases of various chronic illnesses and diseases in today's times are attributed to various types of land,water and air pollution. All over the world people are experiencing the negative effects of environmental degradation and climate change like unhygienic water, water shortage, lack of fish and marine species in the sea, depletion of various flora and fauna and many natural hazards caused due to deforestation, excessive mining and improper management and handling of waste and toxic materials.

A clean and healthy environment is very essential to enjoy a physically and mentally healthy life and for all round development of human society. But due to the poor quality of environment and the natural resources men today is suffering from a lot of health, social and economic issues. The situation of indigenous people in India and elsewhere is even worse as they are directly affected from the damage caused to the ecosystems that they rely upon for their livelihoods.

There are three main components of the interrelationship between human rights and environmental protection:

- $\quad$ The environment as a pre-requisite for the enjoyment of human rights.

${ }^{1}$ Conserve Energy Future, available at https://www.conserve-energy-future.com/what-is-biodiversity.php, visited on 23.07.2019 at $2 ; 45 \mathrm{pm}$ 


\section{GAP GYAN -

- Certain human rights, especially access to information, participation in decision-making, and access to justice in environmental matters, are essential to good environmental decision-making.

- The right to a safe, healthy and ecologically-balanced environment as a human right in itself. ${ }^{2}$

\section{INDIAN LAW AND ENVIRONMENT}

\section{The Constitution of India}

The Constitution of India when originally adopted did not contain any specific provisions regarding the protection of environment. May be, the framers of the Indian Constitution did not consider environment to be a crucial issue back then.

Article 21 of the Constitution of India talks about the right to life and personal liberty, it states that "No person shall be deprived of his life or personal liberty except according to procedure established by law." This article imposes a duty on the state to protect the life and liberty of the people. The Indian Judiciary while dealing with cases relating to environment considered the right to clean or the good environment as fundamental to life and upheld it as a fundamental right. The Judiciary has played a vital role in interpreting the Article 21 of the Indian Constitution.

The scope of Article 21 of the Constitution has been considerably expanded by the Indian Supreme Court, which has interpreted the right of life to mean the right to live a civilized life and it also includes the right to clean environment. ${ }^{3}$ In India after the Stockholm Conference in 1976, under the $42^{\text {nd }}$ Amendment of the Constitution Article 48-A and Article 51-A (g) were inserted in the Indian Constitution. Article 48-A placed environment as responsibility of the state government under the Directive Principles of State Policy. Article 51-A (g) made environmental protection and conservation a Fundamental Duty of all the citizens of India.

\section{LANDMARK JUDGEMENTS}

\section{Mehta v. Union of India (Kanpur Tanneries case) ${ }^{4}$}

A Public interest litigation (P.I.L.) sought an order from the Supreme Court to restrain the tanneries near Kanpur city from discharging trade effluents into the river Ganga until they set up effluent treatment plants. Among other directions, the Court ordered stoppage of work in the tanneries, which were discharging effluents into the river and which did not set up primary treatment plants discharge of untreated wastewater into the river for several years.

\section{Indian Council for Enviro-Legal Action v Union of India and Others ${ }^{5}$}

In this particular case it was alleged that water in wells and streams in village Bichhri in Udaipur district in the State of Rajasthan had become unfit for consumption as a result of disposal of untreated toxic sludge from an industrial complex located within the limits of the village. The Supreme Court held that the respondents were absolutely liable to pay compensation for the harm caused by them to the villagers in the affected area and surrounding areas as well as to the environment.

\section{Vellore Citizens Welfare Forum v Union of India and Others ${ }^{6}$}

The petitioner organization was concerned about water pollution resulting from the discharge of untreated effluents by tanneries and other industries into river Palar in the State of Tamil Nadu, which was a source of drinking water supply. The Supreme Court directed the constitution of an authority under the Environment Act to deal with the situation created by the tanneries and other polluting industries in the State. The authority was also

\footnotetext{
${ }^{2}$ UN Environment,UNEP, available at http://web.unep.org/divisions/delc/human-rights-and-environment, visited on 23.07.2019 at $12: 25 \mathrm{pm}$

${ }^{3}$ Lexpress, 'Right to clean and healthy environment' as a Fundamental Right in India, available at https://lexpress.in/environment/right-clean-healthy-environment-fundamental-right-india, visited on 23.07 .2019 at 5:00pm

${ }^{4}$ M.C.Mehta v Union of India, AIR 1988 SC 1037(India)

${ }^{5}$ Indian Council for Enviro-Legal Action v Union of India and Others, AIR 1996 SC 1446(India)

${ }^{6}$ Vellore Citizens Welfare Forum v Union of India and Others, AIR 1996 SC 2715(India)
} 


\section{GAP GYAN - \\ An International Peer-Reviewed \\ Open Access Journal of Social Sciences}

directed to frame and execute scheme(s) for reversing ecological/environmental damage caused by pollution in the State. It also imposed pollution fine on all the tanneries, and ordered the closure of tanneries that fail to pay the fine.

\section{Rural Litigation and Environment Kendra, Dehradun vs. State of Uttar Pradesh ${ }^{7}$}

In this particular case, before The Supreme Court of India, the representatives of the Rural Litigation and Entitlement Kendra, Dehradun wrote to the Supreme Court that the illegal limestone mining in the MussorieDehradun region was causing damage to environment in that particular region. The Court treated this letter as a public interest petition under Article 32 of the Constitution and after ordering an inquiry into the issue ordered the closure of a number of limestone quarries.

\section{M.C. Mehta vs. Union of India (Vehicular Pollution Case) ${ }^{8}$}

This case was regarding the severe pollution caused in Delhi due to vehicles. The Apex court in this case again confirmed the right to a healthy environment as a basic human right while stating that the right to clean air emanates from Art. 21 which talks about Right to life. This case served as an important landmark judgment. There was a complete phasing out old commercial vehicles more than 5 years old as directed by the courts and also made supply of lead free petrol mandatory in the capital.

\section{Murli S. Deora vs. Union of India9}

In this particular case the Court banned smoking in public places for the protection of environment and human health.

Thus, the Indian environmental scenario is going through a positive change in recent times. Today, the Courts along with the legislative efforts have created environmental consciousness in India and have introduced the Right to Environment as a fundamental right under Article 21 of the constitution of India. The Courts in India have played a major role in helping the people of India lead a qualitative life with dignity.

\section{MARINE ENVIRONMENT}

The oceans and the seas are an indispensable part to support life on earth. The importance of marine biodiversity can be recognized from the very fact that the sea waters cover about $71 \%$ of the earth's surface. The coastal zone represents $18 \%$ of the earth's surface providing space to about $60 \%$ of the human population.

India is rich in terrestrial as well as marine biodiversity. The coastline of India is about $7500 \mathrm{~km}$ wherein a large variety of marine biodiversity including includes lagoons, mangroves, backwaters, salt marshes, rocky coasts, sandy stretches and coral reefs are found.

Humans are dependant for food, medicines, shelter, and livelihood on the seas and the coastal areas. Industries like sea food, tourism and transportation provides livelihood to millions of people around the globe. But various human activities have led to a depletion in fisheries, degradation of the quality of water due to release of toxic substances in the water in turn harming the life forms inhabiting the sea and the entire coastal ecosystem. Hence conservation and preservation of the marine environment has become the need of the hour. But unfortunately the agenda of conservation of marine bio diversity faces a lot of issues like social-economic, economic, environmental, legal as well as scientific and technological.

\footnotetext{
${ }^{7}$ Rural Litigation andEntitlement v. State of U.P. \&Ors,1989 AIR 5941989 SCC Supl. (1) 537 JT 1988 (4) 710 1988 SCALE (2) 1574

${ }^{8}$ M.C.Mehta v. Union of India, 1991 SCR(1)866,1991 SCC(2) 353(India)

${ }^{9}$ Murli S. Deora v. Union of India, 2001 Supp(4) SCR 650(India)
} 
GAP GYAN - An International Peer-Reviewed

Open Access Journal of Social Sciences

\section{INTERNATIONAL INITIATIVES}

The international community has taken many measures to protect, conserve and preserve the marine environment. The famous 'Stockholm Conference' was organized on 1972 and after that United Nations Conference on Environment and Development, popularly known as the 'Rio-Earth Summit', was held on 1992 at Rio De Janeiro. This Earth Summit of 1992 resulted in formation of Convention on Biological Diversity, 1992 along with other agreements on environment.

Many international conferences have been organized and many conventions and treaties have been formed in this regard, e.g. the United Nations Convention on the Law of the Sea, 1982 which deals with the problem of national jurisdiction i.e. the national limits of the contiguous zones, exclusive economic zones, territorial sea and continental shelf. It also dealt with the issues regarding exploitation of resources from the continental shelf and exclusive economic zone. The United Nations Environment Programme (UNEP) Regional Seas Programme, 1974 is an international collaborative approach to protect the marine environment and its resources, the main aim of the Programme is to address the degradation of the seas by engaging neighboring countries in a collaboration to support the achievement of international environment and development targets. The UNEP regional Seas Programme today supports more than 140 countries in marine resources management programmes around the world. ${ }^{10}$

The secretariat of the Convention on Biological Diversity and the Regional Seas Coordinating Unit of UNEP currently focuses on two major activities; (a) the development of a cooperative initiative for the management of marine alien species, also in collaboration with Global Invasive Species Programme, and

(b) The establishment of regional marine protected area networks. The Regional Seas Programme and the secretariat of the Endangered Species Convention, the Whaling Convention, the Convention on Biological Diversity and the Convention on Migrating Species are also collaborating in Marine Mammal Action Plan. ${ }^{11}$

\section{Sustainable Development Goals 2030 or the 2030 Agenda:}

The Sustainable Development Goals (SDGs) or Global Goals for Sustainable Development are a collection of 17 global goals. They are formulated by the United Nations Development Programme.

The said goals cover various socio-economic development issues like global warming, poverty, hunger, health, education, sanitation, environment, energy, urbanization and social justice.

Goal 14 highlights the importance of Life below Water, it reads as follows: "Conserve and sustainably use the oceans, seas and marine resources for sustainable development."12

\section{MARINE ENVIRONMENT AND ISSUES IN INDIA}

\section{The main anticipated sources of marine pollution in India are as follows:}

1. Pollution emitted from the ships and other vessels in the ocean

2. Dumping of hazardous substances into the oceans

3. Pollution from Atmosphere and depletion of Ozone layer

4. Deep Seafloor Mining

5. Pollution from land based activities like agriculture, construction, mining and other commercial activities.

In India efforts have been made to conserve the environment. India has become a signatory to various International instruments and conventions related to marine environment some of which are as follows:

1. United Nations Convention on Law of the Sea(UNCLOS) 1982

\footnotetext{
${ }^{10}$ Biodiversity a-z.UN Environment, WCMC, available at http://www.biodiversitya-z.org/content/unep-regionalseas-programme, visited on 2.11.2018 at 3:50pm

${ }^{11}$ AlokSaxena, Marine Biodiversity in India: Status and Issues, available at http://www.upsbdb.org/pdf/Souvenir2012/ch-14.pdf, visited on 24.07.2019 at 4;00pm

12 Division for Sustainable Development Goals, DESA, available at https://sustainabledevelopment.un.org/?menu=1300, visited on 23.11 .2018 at $4: 15 \mathrm{pm}$
} 


\section{GAP GYAN - $\begin{aligned} & \text { An International Peer-Reviewed } \\ & \text { Open Access Journal of Social Sciences }\end{aligned}$}

2. International Whaling Commission (IWC)

3. CBC (Convention on Biological Diversity)

4. Convention on Migratory Species (CMS) or the Bonn

5. Tuna Commission

6. International Oceanographic Commission

7. Antarctica treaty

8. Agenda 21 is a product of earth summit organized by the United Nations in Rio de Janerio, Brazil 1992.

9. Convention of Wetlands of International importance (Ramsar 1971)

10. The International Convention for prevention of Pollution of Sea by Oil 1954

India has also made various acts and rules in the field of marine environment protection, the main Acts and Rules regulating coastal and marine activities in India include:

1. Indian Fisheries Act 1899 and its amendments in 1920 and 1980

2. Indian Ports Act 1902

3. Merchant Shipping Act 1974

4. Wildlife Protection Act 1972(Amended in 1991 and then in 2002)

5. Water (Prevention and control of Pollution) Act 1974

6. Indian Coast Guard Act 1974

7. Marine Zones of India Act (Regulation of fishing by foreign vessels) Act 1981

7. Environmental Protection Act 1986.

The implementation and execution of the provisions of the acts have never been adequate. At most times these laws are just in paper.

\section{Marine Protected Areas:}

The Indian Judiciary as well as the legislature has constantly indicated at creating more and more marine reserves or Marine Protected Areas (MPAs) in order to achieve the goal of marine environmental protection in the country. The Convention on Biological Diversity (CBD) defines an MPA as "any defined area within or adjacent to the marine environment, together with its overlying waters and associated flora, fauna, and historical and cultural features, which has been reserved by legislation or other effective means, including custom, with the effect that its marine and/or coastal biodiversity enjoys a higher level of protection than its surroundings". ${ }^{13}$ These Marine protected areas are essential to safeguard and sustain the marine biodiversity. If they are maintained properly, they are an effective way of protecting marine ecosystems along with their cultural and historical heritage for the present as well as the future generations. They help in maintain the quality and the productivity of our oceans and act as an insurance policy against impacts of fishing and various other destructive activities going on in the oceans. In India currently there are 128 Marine Protected Ares, out of which there are four Marine National Parks, sixty-seven Marine Sanctuaries, National Parks and Wild Life Sanctuaries, three Marine Biosphere Reserves, three Ramsar Coastal Wetlands, one Tiger Reserve (Sunderbans), one National Mangrove Genetic Resource Centre and Gene Centre and the Coral Reefs of Lakshadweep (seventeen), thirty two Mangrove Notifies Forests. ${ }^{14}$ But the working of these MPAs is not efficient; they haven't been successful in keeping a check on the accumulation of toxic substances thus leading in deterioration of lives of the marine creatures inhabiting the sea.

A high population of India and world consumes seafood; hence this degradation in the quality of the marine creatures affects the health of the humans thus negatively affecting their right to a healthy life. These MPAs are supposed to help in mitigating and avoiding the risks of loss of marine biodiversity but the officials and the concerned staff are not motivated enough to carry out requisite research and development. They also at most times fail to impose necessary sanctions on the polluters and the wrong doers. Mostly it is observed that the big industrial

\footnotetext{
${ }^{13}$ Biodiversity a-z.UN Environment, WCMC, available at http://www.biodiversitya-z.org/content/unep-regionalseas-programme, visited on 24.07.2019 at 3:28pm

${ }^{14}$ P Laxmilatha, T S Sruthy and M S Varsha, Marine Protected Areas, available at http://eprints.cmfri.org.in/10433/1/29_Laxmilatha_1.pdf, visited on 24.07.2019 at 4:00pm
} 


\section{GAP GYAN - $\begin{aligned} & \text { An International Peer-Reviewed } \\ & \text { Open Access Journal of Social Sciences }\end{aligned}$}

houses, shipping companies etc. who are mostly responsible for major percentage of the marine pollution never see them as accountable for the pollution caused by them. So unless and until consciousness and awareness regarding the importance of a healthy marine environment and repercussions of the marine pollution is brought about in the citizens of a country no amount of laws or policies can help bring the environment in balance.

\section{Pollution caused by land based activities:}

Various researches and studies show that approximately eighty percent of marine pollution is caused by land based activities. The hazardous land runoffs are continuously causing harm to the marine environment because hazardous substances are being carried by rivers or by any other water sources and finally enter into the ocean. Surface runoff arising from agricultural farming, commercial activity involved in repairing old structures or constructing new ones, including roads and high ways, buildings and related constructions, seaports or water ports and harbours, carries soil and particles loaded with carbon, phosphorus, nitrogen and minerals. Moreover agriculture and related activities near the coast leads to emission of waste and harmful pesticides loaded with toxic elements into the sea. Therefore, many national and international laws have been enacted for the prevention of land based pollution activities and for the protection of marine environment.

Coastal Regulation Zone notification 1991 under the Environment Protection Act 1986 is an effective means to conserve coastal areas by prohibiting construction activities along the coast.

But it is quit unfortunate that till date these regulations have been ignored at most instances and lot of illegal construction work have been going on near the coast affecting the quality of water and the habitat of the species inhabiting that particular ecosystem.

\section{Ocean Dumping and menace of plastic accumulation in the seas:}

Dumping includes disposal of all types of wastes such as hazardous and toxic industrial waste, waste from ships and tankers, sewerage waste, pharmaceutical and biomedical waste, radioactive waste, atomic waste, chemical waste, dumping of plastic and related waste into the oceans and seas. Of lately a lot of studies have been published regarding the harm caused to the marine ecosystems around the world. Strict laws and fines need to be decided up by the concerned authorities to address this menace of plastic litter near the coasts by tourists as well as the locals.

\section{Oil spillage and pollution caused due to ships:}

Various procedures like cleaning of oil tankers, disposal of cargo residue; accidental collision between ships or sinking of large oil tankers in the ocean leads to pollution in the oceans. A large quantity of oil poured into the sea resulting in marine pollution and death of many sea-borne lives and pollutes oceans, waterways and ports. Large vessels and ships also generate noise pollution that disturbs and disrupts life under water. Therefore, ships are one of the responsible factors of marine pollution.

\section{Pollution from Atmosphere:}

Atmospheric pollution includes highly polluted air, dust and plastic bags blown by the wind, poisonous gases that are emitted from the industries, etc. Acid rain which is a result of climate change and atmospheric pollution (nitrogen oxide and sulphur dioxide) also causes huge damage to the life above water and life under water. Acid rain causes harm to fish and other aquatic animals Due to severe pollution, the level of carbon dioxide is increasing day by day and side by side, the temperature of the atmosphere is also changing. Ozone layer depletion is also causing global warming because it responsible for the arrival of ultraviolet ray on earth. Adoption of a holistic approach to deal with each aspect of environmental pollution whether it is on land, air or water is needed to bring about a positive change in the quality of environment.

\section{Deep Seafloor Mining:}

The sea bed is rich in various types of metals, minerals, stones which yield a high value. supplies e.g., Manganese Crusts, copper, cobalt, nickel, scrap of gold, silver, copper, lead, zinc, platinum etc. Minerals are extracted from the sea floor basically by using drilling method and by using a conveyor-belt or hydraulic pumps or bucket method that bring ore to the surface for processing. Removal of minerals cause disturbance to the habitats of marine life. The sediments that are the outcome of mining also adversely affect under water plants and coral reefs. After mining, rest of the resource particles often float in the sea surface and sometimes crude oil also floats in the sea that is very difficult to remove and consequently, it causes great harm to the marine ecology. Therefore, at present marine 


\section{GAP GYAN - An International Peer-Reviewed Open Access Journal of Social Sciences}

scientific research is being carried on to ascertain the suitable and appropriate method of mining without causing any damage to the marine environment.

\section{CONCLUSION AND SUGGESTIONS}

Our oceans and the seashores provide space to live and directly and indirectly create wealth, including millions of employments in diverse industries such as fishing, aquaculture and tourism. The marine environment includes the water of the ocean, the seabed, its subsoil, all marine life of the sea and coastal habitats. Marine resources are the precious assets and heritage that must be protected, conserved and properly utilized. It gives food in the form of fish and shellfish; it is used for transportation for both travelling and shipping for commercial purposes. It is mined for minerals e.g. salt, sand, gravel, and some manganese, copper, nickel, iron and cobalt can be found in the deep sea and drilled for crude oil .The ocean indirectly contributes in the process of eradication of carbon from the atmosphere and providing oxygen which regulates earth's climate. The ocean also provides resources for biomedical organisms with huge potential for fighting disease.

The oceans have been fished for thousands of years and fishing is an essential part of development of human society. Fisheries are also important to the world economy. Marine environment not only provides food but also natural substances including ingredients for biotechnology and pharmaceuticals. Therefore a clean, healthy and safe marine environment is a part and parcel of the basic human right to live a healthy and fulfilling life.

Though many laws have been made for protection of bio diversity there is still a need for proper implementation and awareness among people. Exploitation of marine bio diversity must be done but it should be done in a sustainable manner.

The detailed records of marine life and changes need to be meticulously recorded. The Indian Ocean Biogeographic Information System (IndOBIS) and Census of Marine Life programs have been launched to pool all the information regarding the marine life and changes happening under the oceans. It is made available through a portal and is internationally accepted data protocol. The concerned people and indigenous communities should be made aware of such technical developments. The selection of suitable sites is an important step towards efficient management and reducing environmental impacts.

The menace of accumulation of plastic and its clearance from the sea needs to be solved. Many national and regional monitoring programs exist for monitoring a variety of pollutants. In India, coastal water quality is being monitored for last 25 years at 24 priority sites. But in spite of such available technologies and research and development opportunities, the quality of marine environment has failed to come at par with other developed countries. Proper legislative measures, socio economic analysis and integrated pollution management practices of both marine and surrounding terrestrial areas are required to develop a sound marine bio diversity conservation strategy.

Environment impact assessment should be carried out in detail, various principles like the polluters pay should be actually put into practice. Various NGOs and Coastal Zone Protection units which are set up in the coastal areas should be provided with necessary technical know-how and financial support.

Moreover scientific research, generating awareness and involvement of local community should be an integral part of every environment protection strategy. 


\section{GAP GYAN - An International Peer-Reviewed Open Access Journal of Social Sciences}

\section{REFRENCES}

$>$ Conserve Energy Future : https://www.conserve-energy-future.com/what-is-biodiversity.php

$>$ UN Environment, UNEP:https://www.unenvironment.org/

$>$ Lex press, 'Right to clean and healthy environment' as a Fundamental Right in India: https://lexpress.in/environment/right-clean-healthy-environment-fundamental-right-india

> Indian Council for Enviro-Legal Action v Union of India and Others, AIR 1996 SC 1446(India)

$>$ Vellore Citizens Welfare Forum v Union of India and Others, AIR 1996 SC 2715(India)

$>$ Rural Litigation and Entitlement v. State of U.P. \&Ors,1989 AIR 5941989 SCC Supl. (1) 537 JT 1988 (4) 710 1988 SCALE (2)1574

$>$ Murli S. Deora v. Union of India, 2001 Supp (4) SCR 650(India)

$>$ Biodiversity a-z.UN Environment, WCMC : http://www.biodiversitya-z.org/content/unep-regional-seasprogramme

$>$ Alok Saxena, Marine Biodiversity in India: Status and Issues: http://www.upsbdb.org/pdf/Souvenir2012/ch-14.pd

> Division for Sustainable Development Goals, DESA: https://sustainabledevelopment.un.org/?menu=1300

$>$ Biodiversity a-z.UN Environment, WCMC: http://www.biodiversitya-z.org/content/unep-regional-seasprogramme

> P Laxmilatha, T. S.Sruthy and M S Varsha, Marine Protected Areas : http://eprints.cmfri.org.in/10433/1/29_Laxmilatha_1.pdf 